\title{
COMPARATIVE ANALYSIS OF ANTHROPOMETRIC DATA OF HAUSAS IN NORTHERN AND SOUTHERN NIGERIA
}

\author{
Adekunle Kolawole ${ }^{1,2}$, Peter Ikubanni ${ }^{2 *}$, Adekunle Adeleke ${ }^{3}$, Olayinka Agboola ${ }^{2}$, Afeez Alebiosu $^{1}$ \\ ${ }^{1}$ Department of Industrial Engineering, University of Ibadan, Ibadan, Nigeria \\ ${ }^{2}$ Department of Mechanical Engineering, Landmark University, Omu-Aran, Nigeria \\ ${ }^{3}$ Department of Mechanical Engineering, University of Ilorin, Ilorin, Nigeria
}

The article aims at obtaining some anthropometric dimensions of Hausa tribes living in both the northern and southern part of Nigeria for the usage of designers of furniture and work stations. Samples of 216 volunteered participants were randomly selected for the study with age range of 16 and 35 years. Sixteen (16) anthropometric dimensions were taken. The descriptive statistical analysis of mean, standard deviations, minimum values, maximum values, $1^{\text {st }}, 5^{\text {th }}, 50^{\text {th }}, 90^{\text {th }}, 95^{\text {th }}$ and $99^{\text {th }}$ percentiles were obtained using SPSS 16.0 statistical package. However, ten selected anthropometric dimensions for T-Test was conducted on the measurements for comparison of all the participants from the north and south; on male participants from north and the south; and on female participants from north and south, at 0.05 level of significance. Most especially for the females, the results showed that there were significant differences in the height, overhead reach, arm span, sitting height, knee height and head length between the Hausa females living in the north and south. Hence, there is the need to design equipment and workplaces which must take into consideration data of the proposed users.

Key words: Anthropometric dimension, Body mass index, Ergonomics, Industrial engineering, Statistical analysis

\section{INTRODUCTION}

Ergonomics is a discipline that applies theory, principles, and methods in the design of work in order to optimize human well-being and overall system performance [1]. It involves such disciplines as industrial engineering, psychology, anthropometry (the science of human measurement), biomechanics (the study of muscular activity) and a few more disciplines to adapt the design of products and workplaces to people's sizes, shapes, physical strengths and limitations. Its objectives are to have effective improvement in work, other human activities and to maintain and enhance certain desirable human values in the process such as health, safety, and satisfaction [2]. More so, it is required that for safety and ergonomics, more researches are expected to be done so that users of products designed will be satisfied [3].

Anthropometry is a branch of ergonomics that is based on the study of the measurement of human body in terms of the dimensions of bone, muscle, and adipose (fat) tissue [4]. Barroso et al. [5] stated that anthropometry consists of measurement of body characteristics such as reach, body segment, length, circumferences, widths and heights among others. The application of these data in design and evaluation of systems, equipment, manufactured products, human-work environments, and facilities was termed engineering anthropometry by [6]. The data from anthropometry can be used to design chairs, work stations, tools, equipments, gloves, socks etc. Adequate anthropometric data is very important in ergonomics and industrial engineering. Due to lack of adequate ergonomics, a fuzzy expert system was established by [7] for identification, evaluation and control of risks factors in a work situation.

In Nigeria, there are researches that have been done in the area of anthropometric data collection and analysis on various ethnic groups, students and occupations in the country. These include the work of [8] where hand, foot, and ear dimensions were obtained from the participants. Through the analysis done, it was reported that the foot breadth is larger for females than for males, and that foot length was larger for males than for females. In another study by [9], a mismatch between the furniture in use by some pupils and their anthropometric data was reported, which could be attributed to one of the major causes of discomfort and distraction in class for the pupils. Hand index classifications of some selected populations of weavers in llorin (North-central Nigeria) for the design of useful hand tools was studied by [10]. The hand classification fell under the hyperdolichocheri hand index group. In order to lessening the health disorders being faced by local weavers in Ilorin, anthropometric data of the local weavers were obtained and comparison was done with the existing seat being used. A mismatch was reported and the study suggested new adjustable seat dimension that will be useful ergonomically for the users [11]. Some other works done as related to engineering anthropometry include [12] on hand anthropometry of agricultural workers in Ibadan, [13] on suitable classroom furniture design specifications for secondary school students in South-west Nigeria, [14] on bus operators in Nigeria, [15] surveyed and obtained the anthropometric data of 
Nigerian adult working class and [16] did a variability study between two Nigeria ethnic groups living in Southwest Nigeria. The collections in these studies were mainly in the southern part of Nigeria. Based on literature, it appears no major survey has been done on engineering anthropometric study in the core northern part of Nigeria. In Nigeria, Hausa tribe is one of the largest and predominant tribes. This study focuses on anthropometric data collection of the Hausa tribe living in the northern part of Nigeria. This study will be of interest to designers and manufacturers of goods or products for the northerners such as motorcycle manufacturers and other professionals. Furthermore, anthropometric data collected was compared with Hausa tribe living in south-western part of Nigeria. The essence is to examine if there are anthropometric discrepancies between the two groups due to location and to make some recommendations thereafter.

\section{MATERIALS AND METHODS}

\section{Volunteered Participant}

This study covers two hundred and sixteen (216) adults which include both male and female. The samples were taken using Hausa tribes in Ibadan (South-Western Nigeria) and Kano (Northern Nigeria). The age range of the volunteers is between 16 and 35 years. Volunteered participants' consents were sought before carrying out the measurement on them for this study.

\section{Measured Dimension}

Sixteen (16) static anthropometric dimensions (such as weight, height, overhead reach, popliteal height, sitting height, arm span, knee height, waist circumference, neck circumference, functional leg length, foot length, foot breadth, head height, head length, hand breadth at thumb and hand length) of the Hausa people living in the northern part and south-western part of Nigeria. The purpose of the survey is to compare the data of the two groups although of the same tribe but living in different parts of the country and observe if there exist any differences between them. Each measured dimension was repeated thrice and the average value derived was utilized. The body mass index, standard deviations, means and inferences of mean were calculated.

\section{Measuring Instruments}

The instruments adopted and used were based on traditional method of measurement which involves the use of simple moveable instruments such as measuring tape, tape rule, anthropometer, weighing scale, chair, vernier caliper and recording sheets (for documentation of the measured dimensions). Some parts such as the popliteal height, head height and length were measured with the anthropometer. Tape rule was used to take the dimensions of the waist circumference, neck circumference and so on. The weighing scale was used to take the weights of the individuals. The measuring tape was used for measurements such as the height, overhead reach and arm span.

\section{Data Collection Procedures}

The procedures involved in data collection for this study were explained to the randomly selected volunteered participants who consented to participate. The personnel were trained, record sheets prepared, age of the participants were recorded, body dimensions taken, body mass index calculated and the obtained data were analyzed.

\section{Data Analysis}

Statistical tools were used to analyze the data. The descriptive statistical analyses carried out include mean, standard deviation and $5^{\text {th }}, 50^{\text {th }}, 95^{\text {th }}$ percentiles of each of the variable. Using SPSS 16.0 statistical package, T-test was conducted on the two groups to verify if there existed significant differences between the two groups or not.

\section{Body Mass Index Calculation}

The body mass index (BMI) is an index that expresses adult weight in relation to height. A BMI of 20 to 25 indicates optimal weight; BMI lower than 20 suggest the person is underweight while a number above 25 indicates the person is overweight. A person may have a BMI below 20 due to disease. A number above 30 suggests the person is obese (over 40, morbidly obese). Mathematically, BMI can be calculated using Eq. (1):

$B M I=$ Weight $/(\text { Height })^{2}$

\section{Percentiles}

Equation (2) was used in calculating percentiles $\left(5^{\text {th }}\right.$, $50^{\text {th }}$, and $\left.95^{\text {th }}\right)$.

$P_{i}=L_{i}+\left(i / F_{p}\right)\left((x \cdot N / 100)-\sum f\right)$

where $i=$ interval, $L_{i}=$ least of the class boundary, $F_{p}=$ frequency of the percentile class, $\Sigma f=$ cumulative frequency down to the class and $N=$ total frequency, $n=$ $1-99$.

\section{RESULTS AND DISCUSSIONS}

A total of 16 dimensions were taken. They were height, overhead reach, functional leg length, arm span, waist circumference, neck circumference, sitting height, knee height, popliteal height, head height, head length, hand length, hand breadth at thumb, foot breadth, foot length and weight. The sample size was 216 volunteered participants comprising of 114 males and 102 females. The data were collected from Kano state as this is the 
heart of the Hausa land. The age range was from 16 to 35 . The body mass index, averages, percentiles and standard deviations were calculated and recorded in the Tables 1 - 3. T-test analyses using SPSS 16.0 statistical package was conducted only on height, overhead reach, arm span, sitting height, head height, head length, hand breadth at thumb, hand length, knee height and popliteal height. Table 1 shows the general sample size that is for the male and female Hausas living in the north while Tables 2 and 3 descriptive statistical analyses of the male and female Hausas living in northern Nigeria, respectively. *All dimensions are in $\mathrm{cm}$ except weight in $\mathrm{kg}$ and body mass index in $\mathrm{kg} / \mathrm{m}^{2}$.

\section{T-Test Analysis}

T-Test was carried out on the two groups. Comparison between the Hausas living in the north $(\mathrm{Hn})$ and the Hausas in the south (Hs) was done as well as comparison between the Hausa males in the north and the Hausa males in the south and Hausa females in the north against the Hausa females in the south of Nigeria. The results obtained are shown in Tables 4 - 6 .

From Tables 2 and 3, the males possess bigger dimensions than the female in most cases. This means when designing for the women or men, different specifications should be used. In the 99th percentile for the height of the two groups, the height of the males was $187.94 \mathrm{~cm}$ while that of the females was $188.12 \mathrm{~cm}$. This signifies that at the 99th percentile, the women are taller than the men. This is a rare occurrence as it was noticed in most of the dimensions the percentile values of the male were higher than that of the female. The mean height for all the volunteered participants in the north is $168.60 \pm 8.34 \mathrm{~cm}$ (Table 1). This falls in the range of the values obtained by [9] for north-central populace and [15] for south-south populace in Nigeria. In Table 4, the Hausas living in the south are relatively bigger than their northern counterparts.

The average height of the Hausas living in the south is $173.99 \mathrm{~cm}$ while that of those living in the north is $168.60 \mathrm{~cm}$ with a difference of $5.39 \mathrm{~cm}$. This indicates that the Hausas in the north are shorter than those living in the south. The popliteal length, head height and hand breadth at thumb of the two groups are similar. This indicates that both of them can use the same type of helmets, seat heights and so on. The other dimensions have significant differences. It is only in the head height that the Hausas living in the north surpass their southern counterparts.

In Table 5 where the males of the two groups were compared, it can be seen that six of the body dimensions are similar. These are the overhead reach, arm span, sitting height, knee height, popliteal height and hand length. This suggests that when designing for the two groups, any product requiring the above named dimensions can work for the two groups. But in the height, head height, head length and hand breadth at thumb, there are significant differences. The southern Hausa men are taller and have longer heads than their northern counterparts but in the head height and hand breadth at thumb, the northern men have bigger sizes than their southern counterparts. This implies for example, in designing helmet for the two groups, different specifications have to be used.

Table 1: Percentiles, mean and standard deviation of Hausa living in the north

\begin{tabular}{|c|c|c|c|c|c|c|c|c|c|c|c|}
\hline \multirow{2}{*}{ No. } & \multirow{2}{*}{ Dimension } & \multirow{2}{*}{ Min } & \multicolumn{6}{|c|}{ Percentiles } & \multirow{2}{*}{ Max } & \multirow{2}{*}{ Mean } & \multirow{2}{*}{$\begin{array}{l}\text { Standard } \\
\text { deviation }\end{array}$} \\
\hline & & & $1^{\mathrm{st}}$ & $5^{\text {th }}$ & $50^{\text {th }}$ & $90^{\text {th }}$ & $95^{\text {th }}$ & $99^{\text {th }}$ & & & \\
\hline 1 & Height & 3.00 & 150.21 & 156.00 & 167.20 & 179.20 & 183.28 & 188.20 & 194.10 & 168.60 & 8.34 \\
\hline 2 & Overhead reach & 178.20 & 186.78 & 196.4 & 215.20 & 232.50 & 235.73 & 249.49 & 251.70 & 216.17 & 13.28 \\
\hline 3 & Arm span & 143.70 & 148.72 & 156.15 & 174.20 & 191.85 & 196.68 & 225.22 & 234.50 & 175.82 & 14.00 \\
\hline 4 & Functional leg length & 77.70 & 85.92 & 90.78 & 99.30 & 105.55 & 106.93 & 108.64 & 109.60 & 99.04 & 5.25 \\
\hline 5 & Waist circumfe & 60.50 & 62.60 & 69.00 & 78.10 & 87.65 & 90.70 & 96.64 & 100.20 & 78.50 & 6.79 \\
\hline 6 & Neck circumference & 24.20 & 25.74 & 29.50 & 33.45 & 39.00 & 39.75 & 41.67 & 43.30 & 34.02 & 3.32 \\
\hline 7 & Sitting height & 70.20 & 73.74 & 77.18 & 82.20 & 87.50 & 89.30 & 93.60 & 94.20 & 82.51 & 3.91 \\
\hline 8 & Knee height & 45.40 & 46.46 & 49.28 & 54.05 & 59.40 & 59.93 & 63.28 & 64.80 & 54.33 & 3.48 \\
\hline 9 & opliteal height & 38.20 & 39.93 & 41.40 & 45.55 & 50.00 & 50.73 & 54.09 & 55.50 & 45.90 & 3.15 \\
\hline 10 & 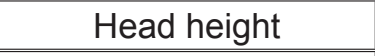 & 20.20 & 20.40 & 20.90 & 22.60 & 24.00 & 24.53 & 25.00 & 25.30 & 22.64 & 1.07 \\
\hline 11 & Head length & 17.70 & 18.02 & 18.20 & 19.60 & 20.95 & 21.53 & 23.51 & 25.00 & 19.73 & .11 \\
\hline 12 & Hand breadth at thumb & 7.60 & 7.92 & 8.40 & & 10.90 & 11.20 & 11.79 & 12.50 & 9.72 & 0.85 \\
\hline 13 & Hand length & 15.50 & 15.83 & 16.73 & 18.90 & 20.60 & 21.20 & 21.79 & 22.00 & 18.87 & 1.32 \\
\hline 14 & Foot breadth & 7.20 & 7.30 & 7.88 & 9.20 & 10.20 & 10.50 & 10.80 & 11.10 & 9.19 & 0.81 \\
\hline 15 & Foot length & 21.50 & 21.90 & 22.20 & 25.20 & 27.50 & 28.10 & 29.16 & 29.60 & 25.11 & 1.75 \\
\hline 16 & Weight & 41.00 & 43.15 & 48.00 & 64.00 & 75.00 & 79.25 & 88.00 & 100.00 & 63.69 & 9.81 \\
\hline 17 & Body mass index & 14.31 & 15.92 & 18.51 & 22.07 & 25.94 & 27.28 & 30.85 & 34.85 & 22.39 & 2.99 \\
\hline
\end{tabular}


Table 2: Percentiles, mean and standard deviation of male Hausas living in the north

\begin{tabular}{|c|c|c|c|c|c|c|c|c|c|c|c|}
\hline \multirow{2}{*}{ No. } & \multirow{2}{*}{ Dimension } & \multirow{2}{*}{ Min } & \multicolumn{6}{|c|}{ Percentiles } & \multirow{2}{*}{ Max } & \multirow{2}{*}{ Mean } & \multirow{2}{*}{$\begin{array}{l}\text { Standard } \\
\text { deviation }\end{array}$} \\
\hline & & & $1^{\text {st }}$ & $5^{\text {th }}$ & $50^{\text {th }}$ & $90^{\text {th }}$ & $95^{\text {th }}$ & $99^{\text {th }}$ & & & \\
\hline 1 & Height & 159.20 & 160.16 & 162.66 & 173.90 & 181.15 & 183.81 & 187.94 & 194.10 & 173.46 & 6.47 \\
\hline 2 & Overhead re & 198.10 & 204.56 & 208.10 & 224.70 & 235.52 & 244.55 & 249.59 & 251.70 & 224.67 & 10.44 \\
\hline 3 & & 160.70 & 161.46 & 170.36 & 183.05 & 195.67 & 205.54 & 230.31 & 234.50 & 184.84 & 12.03 \\
\hline 4 & Functional leg le & 77.70 & 88.94 & 92.46 & 100.60 & 105.60 & 106.94 & 108.24 & 108.70 & 100.07 & 4.93 \\
\hline 5 & Waist circu & 60.50 & 67.94 & 69.39 & 78.55 & 87.67 & 90.28 & 92.76 & 96.80 & & .58 \\
\hline 6 & Neck circumf & 24.20 & 25.34 & 31.72 & 35.50 & 39.70 & 40.74 & 42.05 & 43.30 & 35.69 & 3.39 \\
\hline 7 & & 74.80 & 77.15 & 78.17 & 83.60 & 89.05 & 91.07 & 93.87 & 94.20 & 83.62 & 98 \\
\hline 8 & $r$ & 50.30 & 50.54 & 51.57 & 55.60 & 59.77 & 60.31 & 61.52 & 62.60 & 56.01 & 2.80 \\
\hline 9 & Popliteal nelg & 41.50 & 42.54 & 43.33 & 47.60 & 50.61 & 51.90 & 52.87 & 54.30 & 47.53 & 2.58 \\
\hline 10 & Hondhoight & 20.70 & 21.00 & 21.50 & 22.70 & 23.80 & 23.94 & 24.40 & 25.30 & 22.69 & 0.79 \\
\hline 11 & Head length & 18.10 & 18.10 & 18.20 & 19.45 & 20.60 & 20.80 & 21.19 & 21.70 & 19.50 & 0.82 \\
\hline 12 & Hand breadth at thumb & 8.40 & 8.71 & 9.07 & 10.10 & 11.20 & 11.50 & 11.89 & 12.50 & 10.15 & 0.78 \\
\hline 13 & 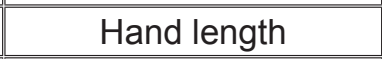 & 17.00 & 17.11 & 17.7 & 19.60 & 21.17 & 21.50 & 21.89 & 22.00 & 19.58 & 1.13 \\
\hline 14 & Foot breadth & 8.00 & 8.01 & 8.57 & 9.60 & 10.50 & 10.70 & 10.97 & 22.00 & 9.62 & 0.65 \\
\hline 15 & Foot length & 22.70 & 23.35 & 24.2 & 26.10 & 28.04 & 28.51 & 29.37 & 29.60 & 26.20 & 1.34 \\
\hline 16 & Weight & 47.00 & 49.13 & 54.65 & 66.00 & 77.40 & 80.00 & 88.00 & 93.00 & 67.08 & 8.18 \\
\hline 17 & Body mass index & 15.91 & 18.00 & 18.74 & 21.93 & 25.58 & 77.30 & 27.66 & 28.29 & 22.29 & 2.43 \\
\hline
\end{tabular}

Table 3: Percentiles, mean and standard deviation of female Hausas living in the north

\begin{tabular}{|c|c|c|c|c|c|c|c|c|c|c|c|}
\hline \multirow{2}{*}{ No. } & \multirow{2}{*}{ Dimension } & \multirow{2}{*}{ Min } & \multicolumn{5}{|c|}{ Percentiles } & \multirow{2}{*}{ Max } & Mean & $\begin{array}{l}\text { Standard } \\
\text { deviation }\end{array}$ \\
\cline { 5 - 10 } & & & $1^{\text {st }}$ & $5^{\text {th }}$ & $50^{\text {th }}$ & $90^{\text {th }}$ & $95^{\text {th }}$ & $99^{\text {th }}$ & & & \\
\hline 1 & Height & 143.00 & 150.21 & 156.00 & 167.20 & 179.20 & 183.28 & 188.20 & 194.10 & 168.60 & 8.34 \\
\hline 2 & Overhead reach & 178.20 & 186.78 & 196.40 & 215.20 & 232.50 & 235.73 & 249.49 & 251.70 & 216.17 & 13.28 \\
\hline 3 & Arm span & 143.70 & 148.72 & 156.15 & 174.20 & 191.85 & 196.68 & 225.22 & 234.50 & 175.82 & 14.00 \\
\hline 4 & Functional leg length & 77.70 & 85.92 & 90.78 & 99.30 & 105.55 & 106.93 & 108.64 & 109.60 & 99.04 & 5.25 \\
\hline 5 & Waist circumference & 60.50 & 62.60 & 69.00 & 78.10 & 87.65 & 90.70 & 96.64 & 100.20 & 78.50 & 6.79 \\
\hline 6 & Neck circumference & 24.20 & 25.74 & 29.50 & 33.45 & 39.00 & 39.75 & 41.67 & 43.30 & 34.02 & 3.32 \\
\hline 7 & Sitting height & 70.20 & 73.74 & 77.18 & 82.20 & 87.50 & 89.30 & 93.60 & 94.20 & 82.51 & 3.91 \\
\hline 8 & Knee height & 45.40 & 46.46 & 49.28 & 54.05 & 59.40 & 59.93 & 63.28 & 64.80 & 54.33 & 3.48 \\
\hline 9 & Popliteal height & 38.20 & 39.93 & 41.40 & 45.55 & 50.00 & 50.73 & 54.09 & 55.50 & 45.90 & 3.15 \\
\hline 10 & Head height & 20.20 & 20.40 & 20.90 & 22.60 & 24.00 & 24.53 & 25.00 & 25.30 & 22.64 & 1.07 \\
\hline 11 & Head length & 17.70 & 18.02 & 18.20 & 19.60 & 20.95 & 21.53 & 23.51 & 25.00 & 19.73 & 1.11 \\
\hline 12 & Hand breadth at thumb & 7.60 & 7.92 & 8.40 & 9.60 & 10.90 & 11.20 & 11.79 & 12.50 & 9.72 & 0.85 \\
\hline 13 & Hand length & 15.50 & 15.83 & 16.73 & 18.90 & 20.60 & 21.20 & 21.79 & 22.00 & 18.87 & 1.32 \\
\hline 14 & Foot breadth & 7.20 & 7.30 & 7.88 & 9.20 & 10.20 & 10.50 & 10.80 & 11.10 & 9.19 & 0.81 \\
\hline 15 & Foot length & 21.50 & 21.90 & 22.20 & 25.20 & 27.50 & 28.10 & 29.16 & 29.60 & 25.11 & 1.75 \\
\hline 16 & Weight & 41.00 & 43.15 & 48.00 & 64.00 & 75.00 & 79.25 & 88.00 & 100.00 & 63.69 & 9.81 \\
\hline 17 & Body mass index & 14.31 & 15.53 & 17.17 & 22.28 & 26.28 & 28.17 & 33.86 & 34.85 & 22.49 & 3.53 \\
\hline
\end{tabular}


Table 4: T-test for all volunteered (Hausa) participants

\begin{tabular}{|c|c|c|c|c|c|c|c|}
\hline \multirow{2}{*}{ No. } & \multirow{2}{*}{ Dimension } & \multicolumn{2}{|c|}{$\mathrm{H}_{\mathrm{n}}=216$} & \multicolumn{2}{|c|}{$\mathrm{H}_{\mathrm{s}}=106$} & \multirow{2}{*}{$\mathrm{t}_{\text {cal }}$} & \multirow{2}{*}{ Decision } \\
\cline { 3 - 7 } & & Mean & $\begin{array}{l}\text { Standard } \\
\text { deviation }\end{array}$ & Mean & $\begin{array}{l}\text { Standard } \\
\text { deviation }\end{array}$ & & \\
\hline 1 & Height & 168.60 & 8.34 & 173.99 & 9.18 & -5.25 & Reject \\
\hline 2 & Overhead reach & 216.17 & 13.28 & 222.50 & 15.01 & -3.21 & Reject \\
\hline 3 & Arm span & 175.82 & 14.00 & 181.57 & 10.08 & -3.51 & Reject \\
\hline 4 & Sitting height & 82.51 & 3.91 & 80.16 & 10.97 & 2.80 & Reject \\
\hline 5 & Knee height & 54.33 & 3.48 & 56.01 & 2.97 & -4.25 & Reject \\
\hline 6 & Popliteal height & 45.90 & 3.15 & 46.34 & 4.91 & 0.97 & Accept \\
\hline 7 & Head height & 22.64 & 1.07 & 22.24 & 1.35 & 2.87 & Reject \\
\hline 8 & Head length & 19.73 & 1.11 & 19.68 & 1.03 & 0.39 & Accept \\
\hline 9 & $\begin{array}{c}\text { Hand breadth at } \\
\text { thumb }\end{array}$ & 9.72 & 0.85 & 9.90 & 1.07 & -1.63 & Accept \\
\hline 10 & Hand length & 18.87 & 1.32 & 19.41 & 1.09 & -3.63 & Reject \\
\hline
\end{tabular}

Table 5: T-test for male Hausas

\begin{tabular}{|c|c|c|c|c|c|c|c|}
\hline \multirow{2}{*}{ No. } & \multirow{2}{*}{ Dimension } & \multicolumn{2}{|c|}{$\mathrm{H}_{\mathrm{n}}=216$} & \multicolumn{2}{|c|}{$\mathrm{H}_{\mathrm{s}}=106$} & \multirow{2}{*}{$\mathrm{t}_{\text {cal }}$} & Decision \\
\cline { 3 - 7 } & & Mean & $\begin{array}{l}\text { Standard } \\
\text { deviation }\end{array}$ & Mean & $\begin{array}{l}\text { Standard } \\
\text { deviation }\end{array}$ & & \\
\hline 1 & Height & 173.46 & 6.47 & 176.43 & 8.15 & -2.75 & Reject \\
\hline 2 & Overhead reach & 224.67 & 10.44 & 226.85 & 12.50 & -1.28 & Accept \\
\hline 3 & Arm span & 184.84 & 12.03 & 184.07 & 8.94 & 0.47 & Accept \\
\hline 4 & Sitting height & 83.62 & 3.98 & 81.31 & 12.73 & 1.81 & Accept \\
\hline 5 & Knee height & 56.01 & 2.80 & 56.61 & 2.82 & -1.42 & Accept \\
\hline 6 & Popliteal height & 47.53 & 2.58 & 47.15 & 5.20 & 0.67 & Accept \\
\hline 7 & Head height & 22.69 & 0.79 & 22.28 & 1.23 & 2.78 & Reject \\
\hline 8 & Head length & 19.50 & 0.82 & 19.7 & 1.08 & -2.01 & Reject \\
\hline 9 & $\begin{array}{c}\text { Hand breadth at } \\
\text { thumb }\end{array}$ & 10.15 & 0.78 & 9.85 & 1.05 & 2.24 & Reject \\
\hline 10 & Hand length & 19.58 & 1.13 & 19.61 & 1.09 & -0.18 & Accept \\
\hline
\end{tabular}

Table 6 shows that there are no significant differences in the dimension of three compared parts for females. These are the popliteal height, head height and head length. Apart from these three, there are significant differences in the other dimensions compared. Except for the sitting height in which the northern female Hausas possess bigger dimension, in the other six, the southerners possess bigger dimensions than their northern counterpart. Further study is recommended to ascertain the reason(s) for this difference.

In the T-test analysis for two groups, it was seen that there exist similarities in only three dimensions of those that were compared at $p<0.05$. These include the popliteal height, head length and hand breadth at thumb, others have significant differences. For the male population, six of the dimensions compared were similar; the overhead reach, arm span, sitting height, knee height, popliteal height and hand length. As for the female population, three of the dimensions were similar; the popliteal height, head height and head length. It was generally observed that the Hausas living in the south are relatively bigger than their northern counterparts. For body parts that are similar, same products can be used by the two groups without discomforting any of them. For those with significant differences, different dimensions have to be used to design in order to avoid discomfort on the part of the other group. 
Table 6: T-test for female Hausas

\begin{tabular}{|c|c|c|c|c|c|c|c||}
\hline \multirow{2}{*}{ No. } & \multirow{2}{*}{ Dimension } & \multicolumn{2}{|c|}{$\mathrm{H}_{\mathrm{n}}=216$} & \multicolumn{2}{|c|}{$\mathrm{H}_{\mathrm{s}}=106$} & \multirow{2}{*}{$\mathrm{t}_{\text {cal }}$} & Decision \\
\cline { 3 - 7 } & & Mean & $\begin{array}{l}\text { Standard } \\
\text { deviation }\end{array}$ & Mean & $\begin{array}{l}\text { Standard } \\
\text { deviation }\end{array}$ & \\
\hline 1 & Height & 163.17 & 6.69 & 169.76 & 9.57 & -4.44 & Reject \\
\hline 2 & Overhead reach & 206.67 & 9.01 & 214.65 & 16.49 & -3.56 & Reject \\
\hline 3 & Arm span & 165.75 & 7.79 & 177.29 & 10.80 & -6.75 & Reject \\
\hline 4 & Sitting height & 81.27 & 3.46 & 78.09 & 5.13 & 4.08 & Reject \\
\hline 5 & Knee height & 52.45 & 3.19 & 54.97 & 2.76 & 4.59 & Reject \\
\hline 6 & Popliteal height & 43.67 & 4.98 & 44.97 & 3.55 & -1.50 & Accept \\
\hline 7 & Head height & 22.58 & 1.31 & 22.29 & 1.74 & 1.03 & Accept \\
\hline 8 & Head length & 19.98 & 1.32 & 19.64 & 0.96 & 1.38 & Accept \\
\hline 9 & $\begin{array}{c}\text { Hand breadth at } \\
\text { thumb }\end{array}$ & 9.23 & 0.64 & 9.80 & 0.94 & -3.97 & Reject \\
\hline 10 & Hand length & 18.07 & 1.02 & 18.97 & 0.96 & -4.52 & Reject \\
\hline
\end{tabular}

The foot length, foot breadth, head length and head height anthropometric dimensions obtained are $25.11 \pm 1.75,9.19 \pm 0.81,19.73 \pm 1.11$ and $22.64 \pm 1.07 \mathrm{~cm}$, respectively, which would serve as a guide in the design and modification of accelerator pedals, clutch pedals, brake pedals, helmets, and foot operated controls and other similar products for foot and head protection as stated by [17]. The mean body mass index (BMI) for all the participants from the north is $22.39 \pm 2.99 \mathrm{~kg} / \mathrm{m}^{2}$. The mean BMl for the male and female participants from the north are $22.29 \pm 2.43$ and $22.49 \pm 3.53 \mathrm{~kg} / \mathrm{m}^{2}$, respectively (Tables 2 and 3). Although the two categories fall under the normal BMI classification, however, the mean BMI for the female is higher than that of the male. From the data obtained, insignificant number of participants falls under the under-weight and over-weight BMI classifications.

\section{CONCLUSION}

The study revealed that data collected could be used in various designs. They can be used in the design of workstations, furniture, helmets, hand gloves, tools and work places. They can also be utilized for the design of automobile parts such as brake pedals, clutch pedals, accelerator pedals and so on. With these data, equipment can be designed for safer usage and more productive use. Discomfort and other health-related issues such as musculoskeletal disorders will be lessened. It is believed that if these data can be made available and utilized before the design, it will be satisfactory to the users. These data will be useful in the design of furniture, doorways, kitchen cabinets and wash hand basins. Personal protective equipment manufacturers can also make use of these data in their designs. It is recommended that based on the discrepancies of some anthropometric dimensions of the same tribe that are living in different regions; anthro- pometric data for same tribe at different regions in the country should be obtained.

\section{REFERENCES}

1. International Ergonomics Association (IEA). (2000). An official definition of ergonomics. Available at http:// www.iea.cc/ergonomics/ accessed on 12/12/2018.

2. Nemeth, C.P. (2004). Human Factors Methods for Design: Making systems Human-Central. Boca Raton: CRC Press. 200NW Corporate Blud..

3. Veljković, Z., Spasojević-Brkić, V., \& Brkić, A. (2015). Crane cabin's safety and ergonomics characteristics evaluation based on data collected in Sweden port. Journal of Applied Engineering Science, vol. 13, no. 4, 299-306.

4. National Health And Nutrition Examination Survey (NHANES). (2005). Anthropometry And Physical Activity Monitor Procedures Manual. Available at https:// www.cdc.gov/nchs/data/nhanes/nhanes_05_06/ BM.pdf.

5. Barroso, M.P., Arezes, P.M., da Costa, L.G., \& Sérgio, M.A. (2005). Anthropometric study of Portuguese workers. International Journal of Industrial Ergonomics, 35(5), 401-410. doi:10.1016/j.ergon.2004.10.005

6. Wagner, D., Birt, J.A., Snyder, M., \& Duncanson, J.P. (1996). Anthropometry and Biomechanics. In Human factors Design Guide. FAA William J. Hughes Technical Center; 14, pp: 18-30.

7. Nunes, I.L. (2012). Fuzzy systems to support industrial engineering management. Journal of Applied Engineering Science, vol. 10, no. 3, 143-146. 
8. Ismaila, O. (2009). Anthropometric data of hand, foot and ear of University students in Nigeria. Leonardo Journal of Sciences, vol. 15, 15-20.

9. Ismaila, S.O., Akanbi, O.G., \& Oderinu, S.O. (2010). Anthropometric survey and appraisal of furniture for Nigerian primary school pupils. E-Journal of Science and Technology, vol. 4, no. 5, 29-36.

10. Ikubanni, P.P., \& Akande, K.A. (2015). Hand index classification of some selected male in Ilorin, North-central Nigeria. E-Journal of Science and Technology, vol. 10, no. 1, 65-69.

11. Ikubanni, P.P., Akande, K.A., \& Agboola, O.O. (2018). Application of anthropometric approach in lessening disorders and stress-related issues. Kathmandu University Journal of Science, Engineering and Technology, 13(1), 45-55. doi:10.3126/kuset.v13i1.21256

12. Okunribido, O.O. (2000). A survey of hand anthropometry of female rural farm workers in Ibadan, Western Nigeria. Ergonomics, 43(2), 282-292. doi:10.1080/001401300184611

13. Ajayeoba, A.O., Oladosu, K.O., Adekoya, L.O., \& Olajimi, A.O. (2016). Ergonomics evaluation and establishment of suitable classroom furniture design specifications for secondary school children in south-west Nigeria. Innovative System and Design Engineering, vol. 7, no. 3, 15-19.
14. Igboanugo, A., Egharevba, F., \& Ibhadode, A. (2002). Anthropometric survey of Nigeria adult working class. Nigerian Journal of Engineering Management, vol. 3, no. 2, 7-20.

15. Onawumi, A.S., Adebiyi, K.A., Fajobi, M., \& Oke, E.O. (2016). Development of predictive models for some anthropometric dimensions of Nigerian occupational bus operators. European Journal of Science and Technology, vol. 5, no. 5, 12-27.

16. Kolawole, A., Charles-Owaba, O., \& Ajisegiri, G. (2009). Anthropometric variability study of two Nigerian ethnic groups. Ergonomics SA, vol. 21, no. 1, 39-51.

17. Onuoha, S.N., Okafor, M.C., \& Oduma, O. (2013). Foot and head anthropometry of 18-30 years old Nigerian polytechnic students. International Journal of Current Engineering and Technology, vol. 3, no. 2, 352-335. 